In the final chapter of the description, Chapter 20, on "Questions", the authors treat both $w h$-questions and yes-no questions. The latter follow the syntax of a declarative sentence with a final rising tone. This chapter also contains sections on words for 'yes' and 'no'.

In conclusion, this is a monumental work, extremely rich in information on and documentation of the Ma'di language. One of the drawbacks is the mixture of a formal analysis and a functional approach, whereby it looks to me that the latter weighs heavier. It is hard to gain a good overview of the structures of the language, both morphological and syntactic, by reading the book. It is not always easy, either, to know in which chapter certain topics are treated. And finally, a number of issues are not handled in usual ways, and certain linguistic terms and concepts cannot always be understood in their traditional way. All in all, the material will be interesting for comparative work between CentralSudanic languages.

Leiden University

Constance Kutsch Lojenga

Maarten Mous: A Grammatical Sketch of Mbugwe: Bantu F34, Tanzania. (Grammatical Analyses of African Languages, Vol. 23.) Cologne: Rüdiger Köppe Verlag, 2004. viii + 70 pp. EUR 23.80.

Mbugwe is a Bantu language spoken around the town of Magugu, Arusha province, in northern Tanzania. Mbugwe (F 34) is most closely related to Rangi (F 33), although the relation of the two to other zone F languages is less clear. There is some unclarity about the numbers of speakers of Mbugwe: Dempwolff (1915/16) has about 10,000 speakers in 1910, and Lucas and Philippson (1973) estimate 5,000 in 1967; Grimes (2004), on the other hand, has a surprising 24,000 speakers in 1999. The neighbours of the Mbugwe are all speakers of non-Bantu languages - Iraqw and Gorwa (Southern Cushitic), Maasai (Eastern Nilotic) and Datooga (Southern Nilotic) - and there is a long history of language contact. There are some older sources (e.g., Dempwolff 1915/16), but, according to Grimes (2004), investigation is needed.

Maarten Mous' short book in Köppe's popular series of grammatical sketches addresses this challenge, and provides us with more information about Mbugwe. The book contains an overview of the grammatical structures of Mbugwe (Phonology, The Verb, Nouns and Nominals, Other Words, and Syntax being the relevant sections), a section with three texts (which, however, I found a bit hard to follow at times), including glossing and translation, and a short Mbugwe-English dictionary with an English-Mbugwe index. However, the author is quick to point out - in the preface - that the description of Mbugwe 
offered in the book is very partial, being based on a very short fieldwork trip, and is thus meant more as a stimulant for further research than as a full description. This impression is enhanced by the presentation of the data, which are often unedited. For example, vowels are presented "phonetically, as I heard them, without regularizing the variation in my data" (5). While this might be honest, it caused me occasional bewilderment later: is the subject concord e- of e-ka-mo-táyra (1-CSEC-1-throw, 'he [the elephant] threw him') as found in the texts (31) a phonetic variant of the class 1 subject concord a- (14), or a different subject concord, not identified in the relevant section, or, indeed, a variant of the class 9 subject concord I-, agreeing with njów, 'elephant' (in which case the gloss provided would be wrong)? In addition, there are a number of irritating editorial problems: "C stands for for any consonant", "palatilised", "that the round vowel does not assimilated" (all page 5; thankfully, it gets better after that); reference to examples 1-25 on page 7 should be to examples 2-26, except for 19 which should be $13 \mathrm{c}$. I thought that a wee bit more editing would have made the sketch ever so much more pleasant to read.

Trivia aside, though, the data presented and their description provide a good glimpse of this interesting language, which holds a number of treats for the discerning Bantuist. Perhaps the most remarkable structure is found in the formation of present progressive, (analytic) future, habitual, and past imperfective. These are formed with a grammaticalized auxiliary verb, which hosts the subject concord, and a lexical verb marked with the infinitive marker $\boldsymbol{\sigma}-/ \mathbf{0}-$, followed optionally by an object marker. However, atypically for Bantu, in Mbugwe, the infinitive precedes the auxiliary (Section 3.2):

$$
\begin{array}{lll}
\text { o-ko-fa } & \text { kó-je } & \text { ng'ombe } \\
\text { 15-2SG-give } & \text { 1PL-come:OPT } & \text { cow } \\
\text { 'we will give you a cow' (31) } &
\end{array}
$$

The example in (1) shows the analytic future tense formed with the auxiliary verb -je, 'come' (with optative inflection) and preceding infinitive with object marking. The accusative/theme object ng'ombe, 'cow', follows the verb. Mous (2000) proposes a diachronic analysis for these (innovative) constructions, adducing external and internal motivation: Externally, the rise of the infinitiveauxiliary construction was supported by structural substrate influence from the neighbouring Cushitic language Iraqw, which has a similar future tense construction. Internally, the new construction was favoured by the merger of the infinitive marker, 2nd singular subject marker and class 1 subject marker (at least in some tenses) to $\mathbf{v - / 0 -}$, so that in many cases subject marking on the first verb could be reanalysed as an infinitive marker (interestingly enough, with the consecutive tense -ka-, used in narration, the subject marker is a-, so that the locus of the proposed reanalysis seems to have been dialogue, not prose). One problematic aspect of this analysis is that neither the external nor 
the internal motivation for this innovation apply very well to the related language Rangi, yet infinitive-auxiliary constructions, involving the copula -rI, are found in Rangi (Mous 2000: 475, Dunham 2004, fc.):

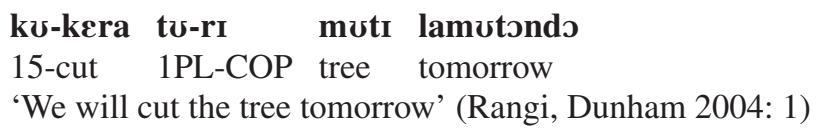

Another syntactic feature of Mbugwe worth mentioning are a number of examples for the fronting of interrogative pronouns (known to some as $w h$-movement) (Section 6.3):

(3) néki w-ànda-ra na motóndo

what 2-PROG-eat with morning

'What do you eat in the morning?' (24)

(4) néki mo-jé-m-pá

what 2PL-FUT-1SG-give

'What will you give me?' (31)

\section{néna n-á-mひ-rokera}

who 1SG-PST-1-leave:APPL

'Whom did I leave?' (24)

Morphologically, the order of passive and applicative extensions in the following example seems remarkable, even if the form-meaning relation is somewhat opaque:

$$
\begin{aligned}
& \text { w-amb-w-er-iye } \\
& \text { 1-tell-PAS-APPL_PF } \\
& \text { 'he told her' }(27)
\end{aligned}
$$

Similarly, the exact description and analysis of a somewhat mysterious "referential" o- may merit further investigation:

$$
\begin{aligned}
& \text { a-ká-o-mo-kóla símba } \\
& \text { 1-CSEC-REF-1-call lion } \\
& \text { 'then she called for lion' (26) }
\end{aligned}
$$

$$
\begin{aligned}
& \text { a-ka-va-o-áye } \\
& \text { 1-CSEC-2-REF-give.birth:PF } \\
& \text { 'she gave birth' (27) }
\end{aligned}
$$

In terms of its function, it is not entirely clear from the context and translations provided in what sense the $\mathbf{0}$ - fulfils a referential role. In the second example (8), the event of giving birth referred to has in fact taken place before, and has already been mentioned, so that in this sense, the predicate in (8) may be 
marked to refer back to this earlier mention. For the example in (7), though, no such previous event of lion calling has been mentioned in the story. A specifically interesting aspect of these examples is the morpheme order in (8), where the referential marker intervenes between object marker and verbal base, again, in an atypical Bantu fashion. It needs to be said, though, that there is no direct translation for (8) in the book, and that my translation omits the contribution of the object marker va-: a class 2 (plural) marker, when in fact the heroine at this stage gave birth to one child only.

In conclusion, then, this short sketch of Mbugwe contains plenty of intriguing material and provides a good first introduction to the main structures of the language. It will lead no doubt to further descriptive, analytical and comparative studies.

School of Oriental and African Studies, London

LUTZ MARTEN

\section{References}

Dempwolff, Otto (1915/16). Beiträge zur Kenntnis der Sprachen in Deutsch-Ostafrika 7. Buwe, 8. Irangi. Zeitschrift für Kolonialsprachen 6: 1-27; 102-123.

Dunham, Margaret (2004). Expressing the future in Langi. Paper presented at the 34th Colloquium on African Languages and Linguistics, University of Leiden, August 2004.

Dunham, Margaret (fc.). Eléments de description du langi, langue bantu F33 de Tanzanie. LouvainParis: Peeters.

Grimes, Barbara F. (ed.) (2004). The Ethnologue. 14th ed. Dallas, Texas: Summer Institute of Linguistics.

Lucas, S. and Gérard Philippson (1973). Ethnic characteristics. In The Population of Tanzania: An Analysis of the 1967 Population Census. Vol. 6., B. Egero and R. Henin (eds.). Dar es Salaam: BRALUP and Bureau of Statistics.

Mous, Maarten (2000). Counter-universal rise of infinitive-auxiliary order in Mbugwe (Tanzania, Bantu F 34). In Mehr als nur Worte ... Afrikanistische Beiträge zum 65. Geburtstag von Franz Rottland, Rainer Voßen, Angelika Mietzner and Antje Meißner (eds.), 469-481. Cologne: Rüdiger Köppe Verlag. 